\title{
Continued mapping of the pre-3760 m.y. old supracrustal rocks of the Isua area, southern West Greenland
}

\section{Jan H. Allaart}

This note reports on the second season's mapping of the Isua supracrustal belt of the Godthåb district (see Allaart, 1975). Following the discovery of the major banded ironstone occurrence at Isua (Keto, 1970), various investigations in the area have been carried out (Moorbath et al., 1973; Bridgwater \& McGregor, 1974; James, 1975). The present mapping is part of the Survey's systematic mapping programme in West Greenland.

The supracrustal belt consists of an incomplete oval-shaped arc around a dome-shaped area of gneiss (fig. 24). The seasons's work appears to make it clear that in those parts of the belt where vertical schistosity and linear elements prevail the rocks have been in amphibolite

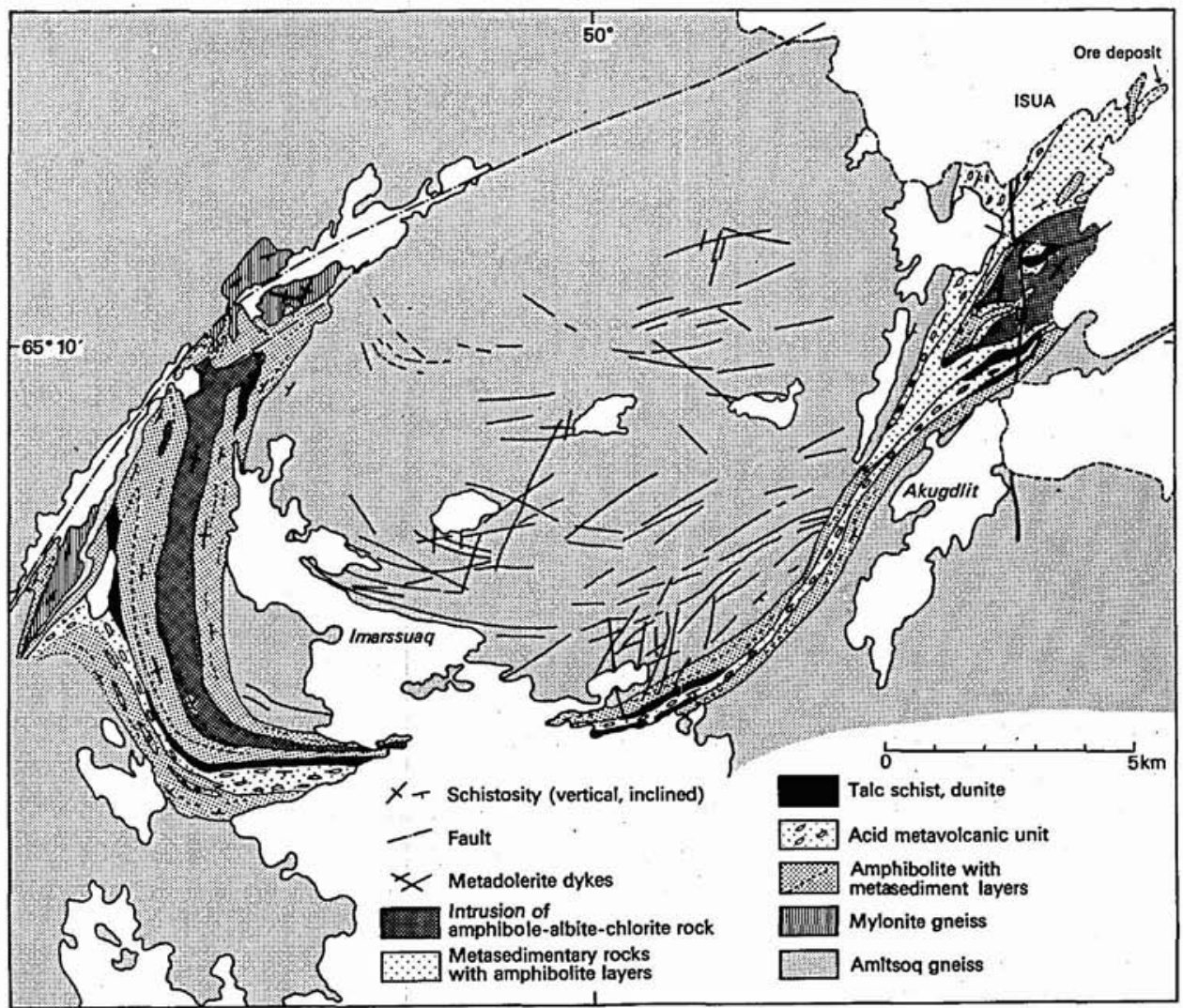

Fig. 24. Geological sketch map of the Archaean Isua supracrustal belt; southern West Greenland. 
facies. Garnet-staurolite schists, originally only found in two localities in the east, occur in continuous zones throughout the belt. Diopside also occurs in many localities over long distances. There does not appear to be any marked metamorphic gradient across the supracrustal belt. However, there are many indications of later retrograde metamorphism, connected partly with deformation, partly with the intrusion of amphibole-albite-chlorite rock with garbenschiefer texture which is thought to have been emplaced relatively late in the chronology.

In the north-western part of the supracrustal belt, areas occur with low to moderately dipping schistosities and variably plunging linear elements. Here, an area over $3 \mathrm{~km}^{2}$ of strongly banded mylonitic gneiss was discovered in which at least two phases of deformation can be recognised. The earliest phase produced a mylonitic fabric in the gneisses. The northernmost mylonitic gneisses are overlain by basic supracrustal rocks. The contact between the gneiss and the supracrustal rocks is folded, and just above the contact quartzite horizons with complicated internal structures are common. The mylonitic gneisses and the supracrustal rocks in the north-western part of the belt are in greenschist facies. In the north-westernmost part of the belt there appears to be a fault between the greenschist rocks and the more high-grade supracrustals with characteristic sub-vertical attitudes of schistosities and linear elements. The westernmost occurrence of mylonitic gneiss is separated from the basic rocks of the belt by a 200-300 m broad zone of gneissose granite (Amîtsoq gneiss ?). Here the mylonitic gneisses are in turn underlain by greenschists in which relics of amphibolite and horizons of carbonate-bearing schists of sedimentary origin occur.

It is tempting to suppose that the mylonitic gneisses represent relics of a major thrust zone below some of the supracrustal rocks of the Isua succession. If the greenschist facies of the rocks above the mylonitic gneisses is prograde, then these greenschist facies rocks might represent a different crustal level from the amphibolite facies rocks of the supracrustal belt. After the thrusting, a second phase of deformation has produced north-south trending folds at the contact between gneisses and supracrustal rocks. It is possible that the gneisses represent a series of arkoses, but in general outlook the rocks are more like migmatites than sedimentary deposits.

Observations in the acid metavolcanic unit, which can be followed continuously over 30 $\mathrm{km}$ from the inland ice to the westernmost part of the belt, have shown that the pyroclastic fragments of rhyolitic, often potassium-rich rock, are most frequent in the west and gradually become less and less common to the east. This might indicate that the original vent which provided the material was situated somewhere close to or in the south-western part of the belt.

In the south-western part of the belt, in a zone $1-2 \mathrm{~km}$ from the outer contact with the Amîtsoq gneisses, conformable zones of fine-grained granitic rocks with a pronounced lineation occur. These rocks may have originated as acid lavas but more work is needed to prove this. It is also possible that these granitic bodies are veins of Amitsoq gneiss which might have intruded the supracrustal belt in an early stage of the metamorphic development.

As has been shown before, carbonate rocks are widespread and occur almost everywhere throughout all the units of the succession. Most of the carbonate material undoubtedly originated as chemical precipitates, but it is also clear that deformation accompanied by metamorphism has caused a high degree of redistribution of carbonate within the rock series. The carbonates are always associated with calc-silicate rocks. In the southern part of the belt 
there is an important horizon at least $10 \mathrm{~km}$ long in which diopside occurs, in many places as giant crystals up to $30 \mathrm{~cm}$ long.

In the westernmost part of the belt there is a clear tendency for the strike of the supracrustal rocks to bend around from north-south, through east-west to north-east - south-west. However, movements along the main ENE trending fault, veining by Amîtsoq gneiss and poor exposures obscure this feature to some extent.

Horizons of banded ironstone and of banded quartzites have been very valuable as marker horizons. It is clear that deformation has been concentrated in the quartzites and in the acid metavolcanic unit in contrast to the amphibolites which apparently behaved as more competent rock units. The quartzites are generally internally folded and in one locality three successive phases of deformation can be detected. Important fold closures have been found only in two places in the supracrustal belt and these are marked by significant horizons of banded ironstone and banded quartzite.

\section{References}

Allaart, J. H. 1975: Field mapping of the pre- 3760 m.y. old supracrustal rocks of the Isua area, southern West Greenland. Rapp. Grønlands geol. Unders. 75, 53-56.

Bridgwater, D. \& McGregor, V. R. 1974: Field work on the very early Precambrian rocks of the Isua area, southern West Greenland. Rapp. Grønlands geol. Unders. 65, 49-54.

James, P. R. 1975: Deformation of the Isua supracrustal belt, southern West Greenland. Rapp. Grønlands geol. Unders. 75, 56-58.

Keto, K. 1970: Isua, a major iron discovery in Greenland. Kryolitselskabet Øresund A/S, 13 pp.

Moorbath, S., O'Nions, R. K. \& Pankhurst, R. J. 1973: An early Archaean age for the Isua iron-formation. Nature phys. Schi. 245, 138-139.

\section{Mapping of Archaean rocks in the inner Godthåbsfjord region, southern West Greenland}

\section{Brian J. Walton}

An area of about $600 \mathrm{~km}^{2}$ was mapped on 1:50 000 scale in the inner part of the Godthåbsfjord region, during the period June to September 1975 (fig. 25). This area is to the north-east of Godthåb and of the classic area described by McGregor (1973). Terminology of the rock units described here are taken from that paper.

The largest part of the studied area is made up of a continuation of the Qôrqut granite which crosses Kapisigdlit fjord, continues north-eastwards through Kangiussap nunâ and could be seen to occur north-east of the upper part of Godthåbsfjord (Kangersuneq). The granite is mainly emplaced within Nûk gneiss but north of Neriunaq it intrudes Amîtsoq gneiss. Another large outcrop of Amitsoq gneiss occurs in the north-west of the area near 